\title{
Local Wisdom in Sustainable Management of Marine Resources: A Case Study of Coastal Communities in Panyula Village Bone Regency
}

\author{
Hasriyanti $^{1}$, Nunuk Parwati Salam ${ }^{2}$, Sartina $^{3}$ \\ 123 JURUSAN GEOGRAFI/ FAKULTAS MATEMATIKA DAN ILMU PENGETAHUAN \\ ALAM/ UNIVERSITAS NEGERI MAKASSAR \\ Email : yantisakijo@yahoo.com \\ salamnunukparwati@gmail.com \\ sartinamaiwa@gmail.com
}

(Received: Agu/2021; Reviewed: Sept/2021; Accepted: Sept/2021; Published: Okt/2021) (https://creativecommons.org/licenses/by-nc/4.0/ ).

\begin{abstract}
Coastal area is an important area to be preserved. Management of coastal areas can be done starting from planning and management must be integrated with socio-cultural, environmental and economic interests. The existence of local wisdom in the community in managing, maintaining and utilizing marine resources can be a filter for modernization that can have a negative impact on social and cultural life as well as the natural environment. The purpose of this paper is to examine and examine the perspective of local wisdom of coastal communities in managing a sustainable environment. The local wisdom of the coastal community of Panyula in sustainable environmental management and is still being carried out today, namely: Mabbaca Doang (Reading Prayers), Massappa Wettu Makanja No Ritasi $e^{\prime}$ (finding a good or right time to go down to the sea), Appakeng Parewa Tasi Mari Olo (use of traditional fishing gear), and Pemmali Lao No' Ritasi'e (abstinence when going out to sea). This local wisdom has a positive influence on the management, utilization, and sustainable development of marine resources. Where the local wisdom contains the rules or norms and culture of the community that are related and useful in efforts to preserve the sustainable coastal environment.
\end{abstract}

Keywords: Local Wisdom; Coastal; Suistainability.

\section{ABSTRAK}

Wilayah pesisir merupakan wilayah yang penting untuk dijaga kelestariannya. Pengelolaan wilayah pesisir dapat dilakukan mulai dari perencanaan dan pengelolaan harus terintegrasi dengan kepentingan sosial budaya, lingkungan dan ekonomi. Eksistensi kearifan lokal di tengah masyarakat dalam mengelola, memelihara dan memanfaatkan sumber daya laut dapat menjadi penyaring modernisasi yang dapat memberikan dampak negatif bagi kehidupan sosial dan 
Hasriyanti, Nunuk Parwati Salam, Sartina, 2021, Kearifan Lokal dalam Pengelolaan Sumber Daya Laut Berkelanjutan: Studi KasusMasyarakat Pesisir di Kelurahan Panyula, Kabupaten Bone

budaya maupun lingkungan alam. Tujuan dari penulisan ini adalah untuk menelaah dan mengkaji perspektif kearifan lokal masyarakat pesisir dalam mengelolah lingkungan yang berkelanjutan. Kearifan lokal masyarakat pesisir Panyula dalam pengelolaan lingkungan berkelanjutan dan masih dilakukan sampai sekarang dan yaitu : Mabbaca Doang (Pembacaan Do'a), Massappa Wettu Makanja No Ritasi e' (mencari waktu yang bagus atau tepat untuk turun ke laut), Appakeng Parewa Tasi Mari Olo (penggunaan alat tangkap tradisional), dan Pemmali Lao No' Ritasi'e (pantangan ketika turun kelaut). Kearifan lokal tersebut memberikan pengaruh positif terhadap pengelolaan, pemanfaatan, maupun pembangunan sumber daya laut berkelanjutan. Dimana kearifan lokal tersebut berisi tentang aturan atau norma-norma dan budaya masyarakat yang memiliki kaitan dan bermanfaat dalam upaya pelestarian lingkungan pesisir berkelanjutan.

Kata Kunci: Kearifan Lokal, Pesisir, Keberlanjutan

\section{PENDAHULUAN}

Indonesia merupakan Negara kepulauan dengan jumlah pulau sekitar 17.499 dari Sabang sampai Merauke dan memiliki panjang garis pantai kurang lebih $81.000 \mathrm{Km}$. Luas total wilayah Indonesia adalah $\pm 7,81$ juta $\mathrm{Km}^{2}$ yang terdiri dari lautan 3,25 juta kmdengan jumlah pulau sekitar 17.499. Dari total luas wilayah Indonesia 3,25 juta $\mathrm{km}^{2}$ adalah lautan, 2,55 juta $\mathrm{km}^{2}$ adalah Zona Ekonomi Eksklusif dan hanya sekitar 2,01 juta $\mathrm{km}^{2}$ yang berupa daratan. Hal tersebut menyebabkan Indonesia sebagai bangsa yang multikultural, salahsatunya yaitu kaya akan berbagai kearifan lokal, menjadi dasar pentingnya integarasi budaya lokal dalam pendidikan dalam membangun budaya kehidupan (Hasriyanti, 2021). Dengan luasnya wilayah laut yang ada, Indonesia memiliki potensi kelautan dan perikanan yang sangat besar. Sektor kelautan dan perikanan memiliki peranan penting dalam pembangunan ekonomi nasional, khususnya dalam penyediaan bahan pangan protein, perolehan devisa dan penyediaan lapangan pekerjaan. Olehnya itu sektor perikanan yang merupakan potensi sumber daya alam perlu untuk dijaga kelestariannya.

Kabupaten Bone merupakan salah satu kabupaten yang terletak di pesisir Timur Provinsi Sulawesi Selatan dan berjarak sekitar $174 \mathrm{~km}$ dari kota Makassar. Luas wilayahnya sekitar $4.559 \mathrm{~km}^{2}$ atau 9,78 persen dari luas Provinsi Sulawesi Selatan. Secara geografis Kabupaten Bone berbatasan sebelah utara dengan Kabupaten Wajo dan Soppeng, sebelah Timur dengan Teluk Bone sebelah Selatan dengan Kabupaten Sinjai dan Gowa dan sebelah Barat berbatassan dengan Kabupaten Maros, Pangkep, Barru. Kabupaten Bone mempunyai garis pantai sepanjang $138 \mathrm{~km}$ (BPS Kabupaten Bone, 2020).

Salah satu Kelurahan yang ada di Kabupaten Bone yang berada di Kec. Tanete Riattang Timur yaitu Kelurahan Panyula yang mayoritas penduduknya bekerja sebagai nelayan. Masyarakat Pesisir Panyula memanfaatkan sumber daya laut sebagai mata pencaharian mereka. Aktivitas masyarakat dalam memanfaatkan sumber daya laut dipengaruhi oleh adat istiadat atau kebiasan yang diwariskan turun temurun oleh pendahulu mereka sampai sekarang melalui proses interaksi sosial. Adat istiadat tersebut biasa disebut dengan kearifan local atau local wisdom.

Kearifan lokal dalam pemanfaatan dan pengelolaan sumberdaya alam pada pesisir dan laut bersifat sistematik dan holistik, di mana manusia dengan segala aktifitasnya tidak dapat 
dipisahkan dengan alam sekitarnya dimana mereka berada, manusia dan alam merupakan satu kesatuan yang dipandang tidak bisa di pisahkan (Mardiana, 2019). Fungsi dan makna kearifan lokal dalam masyarakat sebagai upaya dalam pelestarian sumber daya alam dan manusia, pemertahanan adat dan budaya, serta bermanfaat untuk kehidupan (Fadilah, 2018). Tindakan tersebur diamkani sebagai sebuah bentuk penghargaan kepada para pendahulunya (Ikhsan et al., 2020).

Masyarakat pesisir di Kelurahan Panyula meyakini bahwa kearifan lokal memiliki fungsi dan manfaat dalam pelestarian sumber daya perikanan (aspek produksi) dan ketahanan pangan rumah tangga (aspek konsumsi) sehingga tetap harus dijaga kelestariannya (Ida dkk., 2020). Peluang diversifikasi aktifitas masyarakat pesisit memiliki ketergantungan pada alam yang menyediakan sumber daya, sehingga potensi sumber daya dioptimalkan dalam alternatif diversifikasi pekerjaan (Hasriyanti \& Hendra, 2021). Adapun tujuan diterapkannya kearifan lokal sebagai kontrol terhadap sifat manusia dengan kebutuhan dan keinginannya yang tidak terbatas sangat berpengaruh pada kelestarian lingkungan sebagai tempat tinggal khususnya wilayah pesisir (Juniarta dkk., 2013).

Penting untuk memaknai konsep keberlanjutan lingkungan dalam pemahaman masyarakat hukum lokal (Sulaiman, 2010). Masyarakat dalam hubungannya dengan sumber daya alam, pendekatan ekologi lebih multidimensi, tidak hanya memperhitungkan aspek dan manfaat ekonomi, tetapi juga berbagai aspek dan dimensi lain dipertimbangkan. Menurut (Syarif, 2021) bahwa daerah yang cenderung memiliki karakteristik pedesaan disinyalir masyarakatnya hidup di bawah garis kemiskinan dengan rata-rata sumber daya manusia yang rendah. Lebih lanjut (Syarif, 2021) mengemukakan bahwa penerapan konservasi berkelanjutan sangat penting guna mengakomodir kepentingan penduduk dan sumberdaya alam serta lingkungan laut yang saling berkesinambungan. Hal tersebut dipandang perlu sebagai upaya strategi pemberdayaan sumber daya laut melalui bentuk kearifan lokal (Hasriyanti \& Syarif, 2021). Berangkat dari hal tersebut, maka tulisan ini dimaksudkan untuk melihat bagaimana kearifan lokal berkenaan dengan pengelolaan sumber daya laut berkelanjutan Studi Kasus Masyarakat Pesisir Di Kelurahan Panyula Kabupaten Bone.

\section{METODE}

Penelitian ini dilakukan di Kelurahan Panyyula Kecamatan Tanete Riattang Timur Kabupaten Bone. Penelitian ini dilakukan mulai pada bulan Maret - April 2021. Alat dan bahan yang digunakan dalam penelitian adalah kuisioner survey, perlengkapan alat tulis, tape recorder,dan kamera. Penentuan sampel adalah dengan purpusive sampling. Dalam penelitian ini jumlah responden yang terpilih adalah 20 orang yang mewakili masyarakat nelayan dengan kriteria sebagai orang yang dituakan, keterampilan dalam melaut, tokoh masyarakat.

Data yang diperoleh melalui teknik observasi langsung melalui pengamatan dan wawancara terstruktur dengan menggunakan daftar pertanyaan yang bertujuan untuk mengumpulkan data diri, data sosial - ekonomi serta data terkait kearifan lokal yang digunakan oleh masyarakat nelayan dalam pengelolaan sumberdaya perikanan. Data yang dikumpulkan dalam penelitian ini meliputi data primer dan data sekunder. Pengumpulan data primer dilakukan melalui wawancara dengan menggunakan alat bantu kuisioner untuk menggali informasi terkait keadaan sosial penduduk dan kearifan lokal yang digunakan dalam kegiatan 
Hasriyanti, Nunuk Parwati Salam, Sartina, 2021, Kearifan Lokal dalam Pengelolaan Sumber Daya Laut Berkelanjutan: Studi KasusMasyarakat Pesisir di Kelurahan Panyula, Kabupaten Bone

penangkapan ikan. Data sekunder adalah data yang didapatkan dari penelusuran pustaka dan dari instansi terkait. Data sekunder dapat diperoleh dari Kantor Kelurahan Panyula dan Dinas Kelautan dan Perikanan Kabupaten Bone.

Pengumpulan data dilakukan dengan cara pengamatan/observasi langsung yaitu melakukan observasi mengenai situasi dan kondisi yang terjadi dalam wilayah penelitian, serta konteks sosial lain yang terlibat (Sugiyono, 2018). Metode yang digunakan dalam penelitian ini adalah metode survey dan observasi yang bersifat deskriptif yang bertujuan untuk mendapatkan gambaran faktual dan konkrit mengenai kearifan lokal dalam kegiatan penangkapan ikan di Kelurahan Panyula Kabupaten Bone.

\section{HASIL DAN PEMBAHASAN}

\section{Hasil}

Masyarakat pesisir Panyula memiliki kearifan local yang sampai saat ini masih di lakukan diantaranya adalah sebagai berikut : Mabbaca Doang, Massappa Wettu Makanja No Ritasi e', Appakeng Parewa Tasi Mari Olo, dan Pemmali Lao No' Ritasi'e.

\section{a. Mabbaca Doang}

Mabbaca dalam bahasa Indonesia artinya membaca. Adapun Doang artinya adalah doa. Jadi dapat disimpulkan Mabbaca doang adalah proses pembacaan doa. Tradisi Mabbaca Doang yang dilakukan engan cara dipimpin atau dibacakan oleh sang Guru, yaitu orang yang dipercaya di sebuah daerah/kampung untuk membawakan doa. Biasanya Guru tersebut adalah seorang Imam mesjid setempat, tokoh agama, tokoh adat atau orang yang dihormati di daerah tersebut. Salah satu waktu dilakukannya tradisi Mabbaca doang di Kelurahan Panyula yaitu ketika memiliki kapal baru.

b. Massappa Wettu Makanja No Ritasi e,

Massappa Wettu Makanja No Ritasi'e dalam Bahasa Indonesia berarti mencari waktu, cuaca dan musim yang bagus untuk turun kelaut untuk melakukan penangkapan ikan dimana nelayan percaya bahwa penentuan waktu, cuaca dan musim sangat memberikan pengaruh terhadap keberhasilan penangkapan, jika kegiatan penangkapan dilakukan pada waktu, cuaca dan musim yang sesuai maka kegiatan penangkapan akan mendapatkan hasil yang baik.

c. Appakeng Parewa Tasi Mari Olo

Appakeng parewa tasi mari olo dapat diartikan sebagai penggunaan alat tangkap tradisional. Alat tangkap tradisional yang digunakan masyarakat di kelurahan Panyula diantaranya adalah jala dan purse seine. Para nelayan tidak menggunakan alat tangkap yang berbahaya seperti bom dikarenakan dapat merusak ekosistem dalam laut

d. Pemmali Lao No' Ritasi'e

Pemmali lao no'ritasie dalam bahasa Indonesia diartikan sebagai pantangan ketika turun kelaut yaitu pada saat nelayan memulai berlayar ke tengah laut atau muara untuk mencari ikan, para nelayan harus menghindari beberapa hal hal yang tidak boleh atau pantang dilakukan yaitu mengeluarkan bahasa yang kotor dan tidak sopan, pantangan buang air kecil dan air besar, selama perjalanan menuju ke tengah laut untuk mencari ikan.

Ada 1 jenis kearifan lokal yang sudah ditinggalkan atau mulai pudar ditengah masyarakat Panyula yaitu, Mappano parewa tasi pattikeng bale (melaksanakan ritual menenggelamkan salah satu alat tangkap ke laut sebagai sebuah sesaji). Hal tersebut 
Hasriyanti, Nunuk Parwati Salam, Sartina, 2021, Kearifan Lokal dalam Pengelolaan Sumber Daya Laut Berkelanjutan: Studi KasusMasyarakat Pesisir di Kelurahan Panyula, Kabupaten Bone

dikarenakan bertentangan atau tidak sesuai dengan ajaran agama Islam, dimana mayoritas masyarakat Panyula memeluk agama Islam.

\section{Pembahasan}

Kearifan lokal masyarakat pesisir Panyula yang masih dilakukan sampai sekarang adalah, Mabbaca Doang (Pembacaan Do'a), Massappa Wettu Makanja No Ritasi e' (mencari waktu yang bagus atau tepat untuk turun ke laut), Appakeng Parewa Tasi Mari Olo (penggunaan alat tangkap tradisional), dan Pemmali Lao No' Ritasi'e (pantangan ketika turun kelaut). Kearifan lokal tersebut memberikan pengaruh positif terhadap pengelolaan, pemanfaatan, maupun pembangunan sumber daya laut berkelanjutan.

\section{Mabbaca Doang}

Kearifan lokal ini dapat dijadikan sebagai norma yang harus dijaga oleh masyarakat sehingga masyarakat peduli terhadap diri sendi sendiri dan juga lingkungannya. Secara tidak langsung memiliki rasa mawas diri untuk selalu berhati-hati dan melakukan hal-hal yang tidak membahayakan dalam melakukan kegiatan menangkap ikan yaitu memperhatikan keselamatannya dan juga pelestarian lingkungan laut.

\section{Massappa Wettu Makanja No Ritasi e'}

Massappa Wettu Makanja No Ritasi e' (mencari waktu, cuaca dan musim yang bagus untuk turun kelaut) dapat dijadikan sebagai cara masyarakat dalam menangkap ikan dengan mempertimbangkan keadaan lingkungan. Sehingga kearifan lokal berisi pengetahuan masyarakat melihat kondisi cuaca atau musim yang memungkinkan untuk mendapatkan hasil tangkapan ikan yang bagus. Sejak dulu masyarakat meyakini jika terjadi

\section{Appakeng Parewa Tasi Mari Olo}

Adapun kearifan lokan Appakeng Parewa Tasi Mari Olo (penggunaan alat tangkap tradisional) merupakan bentuk kepedulian masyarakat terhadap ekosistem laut, sehingga dengan adanya kearifan lokal ini masyarakat selalu menyadari akan pentingnya menjaga lingkungan. Masyarakat meyakini bahwa penggunaan alat tangkap tradisional dapat menjaga dan mempertahankan kondisi potensi sumber daya perikanan. Hal tersebut dikarenakan hasil tangkapan dengan menggunakan alat tradisional lebih selektif dan lebih efisien. Menggunakan bom dalam menangkap ikan, kemungkinan dapat memberikan hasil tangkapan yang banyak dan memperolehnya lebih cepat namun hal tersebut dapat merusak ekosistem bawah laut dan dapat menyebabkan potensi perikanan yang kurang baik.

\section{Pemmali Lao No' Ritasi'e}

Kearifan lokal Pemmali Lao No' Ritasi'e (pantangan ketika turun kelaut) juga dapat dijadikan sebagai norma atau adab masyarakat pesisir Panyula ketika melakukan aktifitas menangkap ikan dilaut. Mereka tidak melakukan hal-hal yang tidak baik, seperti mengeluarkan kata-kata yang tidak baik atau tidak sopan, mengotori laut dengan buang air kecil maupun air besar selama perjalanan menuju ke tengah laut. Hal ini juga memberikan dampak positif terhadap pelestarian lingkungan, karena dengan begitu masyarakat selalu memperhatikan kelestarian lingkungan laut yang merupakan tempat mereka mencari penghidupan dengan bekerja sebagai nelayan.

Selain itu ada satu kearifan lokal yang mulai pudar yaitu Mappano parewa tasi pattikeng bale (melaksanakan ritual menenggelamkan salah satu alat tangkap ke laut sebagai sebuah sesaji), alasan masyarakat tidak melaksanakan lagi karena menganggap tidak relevan 
Hasriyanti, Nunuk Parwati Salam, Sartina, 2021, Kearifan Lokal dalam Pengelolaan Sumber Daya Laut Berkelanjutan: Studi KasusMasyarakat Pesisir di Kelurahan Panyula, Kabupaten Bone

dan tidak sesuai dengan ajaran agama Islam, dimana untuk melakukan aktivitas kesehariaanya mereka memohon keselamatan dengan berdoa hanya kepada Allah Subehana Wata'ala.

Kearifan lokal dapat terbentuk dari pengalaman hidup yang panjang, sehingga menjadi bagian dari gaya hidup (life style) masyarakat setempat dengan norma-norma sosialnya yang berlaku. Kearifan lokal menjadi benteng yang sangat penting dalam upaya pengelolaan lingkungan hidup dan pengelolaan sumber daya laut berkelanjutan. Eksistensi kearifan lokal di tengah masyarakat dalam mengelola, memelihara dan memanfaatkan sumber daya laut dapat menjadi penyaring modernisasi yang dapat memberikan dampak negatif bagi kehidupan sosial dan budaya maupun lingkungan alam.

\section{SIMPULAN DAN SARAN}

\section{Simpulan}

Mayarakat Pesisir Panyula Kabupaten Bone dalam memanfaatkan sumber daya laut dipengaruhi oleh adat istiadat atau kebiasan yang diwariskan turun temurun oleh pendahulu mereka sampai sekarang melalui proses interaksi sosial yang disebut dengan kearifan lokal. Kearifan lokal yang masih dilakukan masyarakat sampai sekarang adalah sebagai berikut : Mabbaca Doang (Pembacaan Do'a), Massappa Wettu Makanja No Ritasi e' (mencari waktu yang bagus atau tepat untuk turun ke laut), Appakeng Parewa Tasi Mari Olo (penggunaan alat tangkap tradisional), dan Pemmali Lao No' Ritasi'e (pantangan ketika turun kelaut). Kearifan lokal tersebut memberikan dampak positif yaitu sebagai upaya dalam pengelolaan, pemanfaatan, maupun pembangunan sumber daya laut berkelanjutan.

Kearifan lokal tersebut berisi aturan atau norma-norma tersebut menjadi banteng terhadap dampak negatif globalisasi dan modernisasi dalam kegiatan pengelolaan lingkungan berkelanjutan. Seperti dalam penggunaan alat tangkap tradisional masyarakat meyakini hal tersebut dapat menjaga dan mempertahankan potensi sumber daya perikanan yang ada. dikarenakan hasil tangkapan dengan menggunakan alat tradisional lebih selektif dan lebih efisien. Sedangkan penggunaan bom dengan proses yang cepat dan tangkapan yang banyak dapat merusak ekosistem bawah laut dan dapat menyebabkan penurunan potensi perikanan.

\section{Saran}

Dalam merumuskan kebijakan dalam pengelolaan, pemanfaatan, maupun pembangunan sumber daya laut dan pesisir di Kelurahan Panyula, Kecamatan Tanete Riattang Timur Kabupaten Bone, perlu dipertimbangkan kearifan lokal yang ada. Terlebih jika hal tersebut sesuai atau tidak bertentangan dengan konsep pembangunan berkelanjutan yaitu pembangunan yang selain melihat aspek ekonominya juga mempertimbangkan aspek lingkungan. Hal tersebut penting dilakukan guna terwujudnya kehidupan yang harmonis antara manusia dan lingkungan alam sekitanya, sehingga memberikan hasil yang optimal.

\section{DAFTAR RUJUKAN}

BPS Kabupaten Bone. (2020). Kabupaten Bone Dalam Angka. BPS Kab. Bone. Fadilah, M. (2018). Kearifan Lokal Sebagai Ketahana Pangan. UIN Syarif Hidayatullah Jakarta. 
Hasriyanti, Nunuk Parwati Salam, Sartina, 2021, Kearifan Lokal dalam Pengelolaan Sumber Daya Laut Berkelanjutan: Studi KasusMasyarakat Pesisir di Kelurahan Panyula, Kabupaten Bone

Hasriyanti, H. (2021). Pembelajaran Terintegrasi Budaya Lokal Melalui Tradisi Maccera Siwanua. LaGeografia, 19(2), 251-261.

Hasriyanti, H., \& Syarif, E. (2021). STRATEGI PEMBERDAYAAN SUMBER DAYA LAUT MELALUI KEARIFAN LOKAL SISTEM PUNGGAWA-SAWI DI DESA PALALAKKANG KECAMATAN GALESONG KABUPATEN TAKALAR. Jurnal Environmental Science, 3(2).

Hasriyanti, H., \& Hendra, H. (2021). DIVERSIFIKASI PEKERJAAN SEBAGAI STRATEGI BERTAHAN HIDUP RUMAH TANGGA NELAYAN DI GALESONG UTARA. JAMBURA GEO EDUCATION JOURNAL, 2(2), 63-69.

Ida, R., Nurliani, \& A.Gobel, F. (2020). Profil Kearifan Lokal dalam Menunjang Ketahanan Pangan Rumah Tangga pada Agroekosistem Pesisir. Universitas Muslim Indonesia.

Ikhsan, A. M., Hasriyanti, H., \& Syarif, E. (2020). Pendidikan Formal Anak Dalam Perspektif Nelayan Suku Bajo di Kampung Bajo. LaGeografia, 18(3), 269-288.

Juniarta, H. P., Susilo, E., \& Primyastanto, M. (2013). Kajian Profil Kearifan Lokal Masyarakat Pesisir Pulau Gili Kecamatan Sumberasih Kabupaten Probolinggo Jawa Timur. Jurnal ECSOFiM, Vol. 1 No. 1.

Mardiana, S. (2019). Kearifan Lokal dalam Pengelolaan Pesisir Berkelanjutan Sumatera Utara: Studi Kasus Masyarakat Pesisir Timur Sumatera Utara. Vol. I(1), 9.

Syarif, E. (2021). Dynamics of Education of Fishermen's Children in Tanakeke Island in Phenomenological Perspective. Indonesian Journal of Educational Studies, 24(1), 64-71.

Syarif, E. (2021). Fundamental Study of Marine Resource Conservation Wisdom for Traditional Fishermen. Indonesian Journal of Fundamental Sciences, 7(1), 29-39.

Sugiyono, P. (2018). Metode Penelitian Kuantitatif,Kualitatif dan R \& D. Alfabeta.

Sulaiman. (2010). Model Alternatif Pengelolaan Perikanan Berbasis Hukum Adat Laot Di Kabupaten Aceh Jaya Menuju Keberlanjutan Lingkungan Yang Berorientasi Kesejahteraan Masyarakat. Universitas Diponegoro Semarang. 